BILANÇOLAR ILE TÜRK INŞAAT SEKTÖRÜNÜN FINANSAL YAPISININ DEGERLENDIRILMESI

FINANCIAL STRUCTURE EVALUATION OF THE TURKISH CONSTRUCTION INDUSTRY VIA BALANCE SHEETS

\title{
Dr. Gülben ÇALIŞ
}

EgeÜniversitesi, MühendislikFakültesi, İnşaatMühendisliğiBölümü, Bornova, İzmir 35100 TURKEY

gulben.calis@ege.edu.tr

ÖZET

Tekstil, gıda, otomotiv gibi sektörler, finansal yapılarının incelenmesi bakımından ilgi çekmiş ve bu sektördeki şirketler için kullanılabilecek kıyaslama oranları bilançolar aracılığıyla ortaya konulmuştur. Ancak, inşaat sektörünün heterojen yapıda olması dolayısıyla bu alanda yeterince çalışma yapılmadı̆̆ı görülmektedir.

Bu çalışmada, inşaat sektöründe faaliyet gösteren şirketlerin bilançolarından faydalanarak, Türk inşaat sektörünün finansal yapısı değerlendirilmektedir. Çalışma kapsamında, Türkiye Cumhuriyeti Merkez Bankası'nca 2001-2011 yılları arasında yayınlanan toplam 8844 inşaat şirketinin bilançoları incelenmiştir.Değerlendirme, inşaat sektöründe alt sektörlerin karakterlerinin çok farklılık göstermesi nedeniyle, kayıtlı olan şirketlerin ağırıklı olarak çalıştıkları ihale usulü işlere göre yapılmıştır.

Anahtar kelimeler:Inşaat sektörü, finansal yapı, bilanço analizi, Türkiye

\section{ABSTRACT}

Investigating financial structures of industries like textile, food and automotive have drawn interest and ratios for benchmarking have been set via balance sheets for these industries. However, there are not enough studies in this area for the construction industry due to its heterogenic structure.

In this study, financial structure of the Turkish construction industry is evaluated via balance sheets of the construction companies. A total of 8844 balance sheets published by the Central Bank of the Republic of Turkey for the years between 2001 and 2011 have been evaluated. Due tothe varyingcharactersof the subsectors in the construction industry, assessment has been done mainly based on the registered companies which are in the procurement works.

Keywords:Construction industry, financial structure, balance sheet analysis,Turkey. 1.GiRiş

Bilançolar, işletmelerin finansal yapıları hakkında bilgi veren en önemli araçlardan biri olup şirketlerin finansal analizleri için veri sağlamaktadır. Bir şirketin borç alabilmesi, hisse senedi çıkarabilmesi, tahvil sata- 
bilmesi, stok politikasının iyi olup olmadığı, çalışma sermayesinin yeterli olup olmadığı, yatırım yaparken hangi fon kaynağının kullanılacağı gibi konular ele alınırken, şirketin içinde bulunduğu sektörün de göz önünde bulundurulması gerekmektedir. Tekstil, gıda, otomotiv gibi sektörlerin finansal yapıları bu anlamda incelenmiş, ancak inşaat sektörü yapısı gereği yeterince incelenememiştir. Yapılan kısıtlı sayıdaki çalışmalardan birinde, finansal oranlar ve Altman Z-score modeli Çin'deki müteahhitlerin performanslarını değerlendirmek için kullanılmıştır (Ng ve diğ., 2011). Çetin (2002), 1995-2000 yılları arasında yayınlanmış bilançoları inceleyerek, şirket yapılarına ait ortak ölçütler koymaya çalışmıştır. Bir diğer çalışma, Türk inşaat sektöründe finansal yapıyı yansıtmak için kullanılabilecek finansal oranları araştırmıştır (Öcal ve diğ., 2007). Görüldüğü üzere, inşaat sektöründe çalışacak kişilere yardımcı olmak üzere daha fazla araştırmaya gerek duyulmakta ve öncelikle sektörün ana yapısının tanıtılması gerektiği açıktır.

İnşaat sektörü Türk ekonomisinin en önemli üç sektöründen bir tanesidir (Çetin, 2002). Gerek yoğun istihdam yeteneği gerekse diğer sektörlerle girdi çıktı ilişkileri sektörün önemini daha da arttırmaktadır. Türkiye'de yaklaşık 270 sanayi dalıyla girdi ilişkisinde bulunması nedeniyle, sektördeki canlılık veya durgunluk diğer sektörleri ve ülke ekonomisini kısa zamanda ve önemli biçimde etkiler (Akal ve diğ., 1983). Sektörde yerli ürünlerin çoğunlukta olması, ülke ve bu ürünleri üreten şirketler için önemli olmaktadır. İnşaat sektöründeki küçülmenin en başta işsizlik olmak üzere ekonominin geneline çok ciddi yansımaları olduğu kuşkusuzdur. Sektörde yoğun istihdam sağlanması, birçok vasıfsız işçiye de çalısma olanağı yaratması sosyal açıdan önemli bir katkıdır (iTO Seminer, 1988). Sektör büyük olmasına rağmen tamamen gelişememiştir. Uzun vadeli yatırımlar için gerekli sistem oluşturulamamış, sağlıklı bir işleyiş sağlanamamıştır. Riskleri fazla olan bir sektör olup konjonktürel dalgalanmalardan ilk etkilenen sektördür. Ekonomik durgunluklarda yatırımların kısıtlanması, ödeneklerin kısılması sektörü derinden etkilemektedir.Üretim biçimi, hukuksal ve ekonomik yapısı diğer sektörlerden farklıdır. Diğer sektörlerde üretim sürekli ve üretilen aynı olmasına karşın, inşaat sektöründe işler kesikli (1-5 yıl arasında süregelen işler) olmakta (proje tipi üretim), bitirilen işten sonra yeni bir işin bulunması belirsiz olmakta, yeni iş alınsa bile bunun bir önceki ile aynı olması olasılığı zayıf olmaktadır. Bu yapı duran varlıklardaki makine-teçhizat kalemini küçültmektedir.

Türk inşaat sektöründe 2002-2007 arasındaki dönemde özellikle konut talebi patlamasının rol oynadığı inişli çıkışlı bir büyüme yaşanmıştır. Konut talebinin 2006'nın ikinci yarısında hız kesmesiyle inşaat sektöründeki büyüme hızı gerilemeye başlamış ve 2008 yılında konut talebi gerilemesine küresel krizin olumsuz etkilerinin de eklenmesi ile sektör \%7,6 oranında küçülmüştür. İnşaat sektörünün büyüme performansında önemli bir yeri olan kamu inşaat yatıımları 2009 yılındaki yerel seçimlerin de etkisiyle artmış, buna karşın özel sektörün inşaat yatııımları \%28,8 azalmıştır (TMB, 2009). Oldukça değişkenlik gösteren sektörde finansal yapının önemi ortaya çıkmaktadır.

Bu çalışmada Türkiye Cumhuriyeti Merkez Bankası (TCMB) tarafından 2001-2011 yılları arasında yayınlanan inşaat şirketinin bilanço verileri incelenmiştir. Çalışmanın amacl; yapılan değerlendirmeler sonucunda in- 
şaat sektörünün finansal yapısını yansıtmaktır. Bu kapsamda öncelikle incelenen inşaat şirketlerinin profili anlatılacak, sonraki bölümlerde inşaat sektörünün aktif ve pasif yapıları incelenerek bilanço analizi yapılacaktır.

\section{INCELENEN INŞAAT ŞIRKETLERININ PROFILI}

Bu çalışmada 2001 ve 2011 yılları arasında T.C. Merkez Bankası'nın yayınlamış olduğu inşaat sektöründe faaliyet gösteren şirketlere ait bilançolardan yararlanılmıştır (TCMB Sektör Bilançoları, 2013). Toplam 8844 adet inşaat şirketi bilançosu incelemeye konu olmuştur. Tablo 1. incelenen inşaat şirketlerinin türlerine göre dağılımını göstermektedir. 1979 yıında yapılan bir araştırmaya göre 1968-1978 yılları arasında 460 inşaat yüklenicisi arasında yapılan bir çalışmada yüklenicilerin \%2'sinin sermaye, \%17'sinin şahıs şirketi, geri kalanların da adi ortaklık olduğu belirlenmişti (Yüksel, 1979). 1999 yılında Bayındırlık ve İskan Bakanlığı'ndan elde edilen verilere göre 69379 kayıtlı yüklenici bulunduğu, bunları 21669'unun ticari şirket, geri kalan 45710'unun ise şahıs yüklenici karnesi aldığı belirtilmektedir (Manisalı ve Gencer, 2000).

Tablo 1. değerlerine bakıldığında sektörün sermaye şirketlerine yöneldiği görülmektedir. 1970'li yıllarda sektörde faaliyet gösteren şirketlerin \%98'inin şahıs şirketi olduğu, 2000'li yıllarda ise bu durumun tam tersine dönerek \%98'inin sermaye şirketi olması dikkat çekicidir. Bu yönelişle şirketlerin yeniden değerlendirme ile amortisman paylarını yükseltebilmekte, bazı giderlerini (yakıt giderleri... vb.) daha rahat masraf olarak gösterilebilmektedirler. Ancak, inşaat sektörünün duran varlıklarının diğer sektörlere göre daha düşük olduğu da unutulmamalıdır. 
Tablo 1.Inşaat şirketlerinin türlerine göre dağılımı

\begin{tabular}{|c|c|c|c|c|c|c|c|c|c|c|}
\hline & $\begin{array}{l}\text { Ano- } \\
\text { nim }\end{array}$ & $\begin{array}{l}\text { Limi- } \\
\text { ted }\end{array}$ & $\begin{array}{l}\text { Koman- } \\
\text { dit }\end{array}$ & $\begin{array}{l}\text { Kolek- } \\
\text { tif }\end{array}$ & Şahıs & \begin{tabular}{|l|} 
Adi \\
mandit
\end{tabular} & $\begin{array}{l}\text { Ko-Koope- } \\
\text { ratif }\end{array}$ & Kamu & $\begin{array}{l}\text { Hol- } \\
\text { ding }\end{array}$ & $\begin{array}{l}\text { Vakıf } \mid \begin{array}{l}\text { TOP- } \\
\text { LAM }\end{array} \\
\text {. }\end{array}$ \\
\hline 2 Adet & 364 & 354 & 1 & 5 & 36 & 2 & - & - & $F$ & 762 \\
\hline$\left|\begin{array}{l}0 \\
0 \\
1\end{array}\right| \%$ & 47,8 & 46,4 & 0,1 & 0,7 & 4,7 & 0,3 & - & - & - & \\
\hline \begin{tabular}{|l|l}
22 & Adet
\end{tabular} & 338 & 329 & - & 6 & 27 & 1 & $F$ & $F$ & $F$ & 701 \\
\hline $\begin{array}{c}0 \\
0 \\
0 \\
2\end{array} \mid \%$ & 48,2 & 46,9 & - & 0,9 & 3,9 & 0,1 & - & - & - & \\
\hline 2 Adet & 342 & 345 & 1 & 4 & 25 & 1 & - & 1 & $F$ & 719 \\
\hline$\left[\begin{array}{l}0 \\
0 \\
3\end{array} \mid \%\right.$ & 47,6 & 48,0 & 0,1 & 0,6 & 3,5 & 0,1 & F & 0,1 & - & \\
\hline 2 Adet & 343 & 341 & 1 & 5 & 18 & 1 & - & - & 1 & 710 \\
\hline$\left(\begin{array}{l}0 \\
0 \\
4\end{array} \mid \%\right.$ & 48,3 & 48,0 & 0,1 & 0,8 & 2,6 & 0,1 & - & - & 0,1 & - \\
\hline 2 Adet & 350 & 328 & 2 & 3 & 17 & - & - & - & F & 700 \\
\hline$\left|\begin{array}{l}0 \\
0 \\
0 \\
5\end{array}\right| \%$ & 50,0 & 46,9 & 0,3 & 0,4 & 2,4 & - & - & - & - & - \\
\hline 2 Adet & 404 & 308 & 1 & 1 & 17 & 1 & 1 & - & - & 733 \\
\hline $\begin{array}{l}0 \\
0 \\
6\end{array} \mid \%$ & 55,2 & 42,0 & 0,1 & 0,1 & 2,4 & 0,1 & 0,1 & - & & \\
\hline \begin{tabular}{|l|l} 
Adet \\
\end{tabular} & 436 & 342 & 1 & 1 & 15 & 3 & - & - & & 798 \\
\hline
\end{tabular}




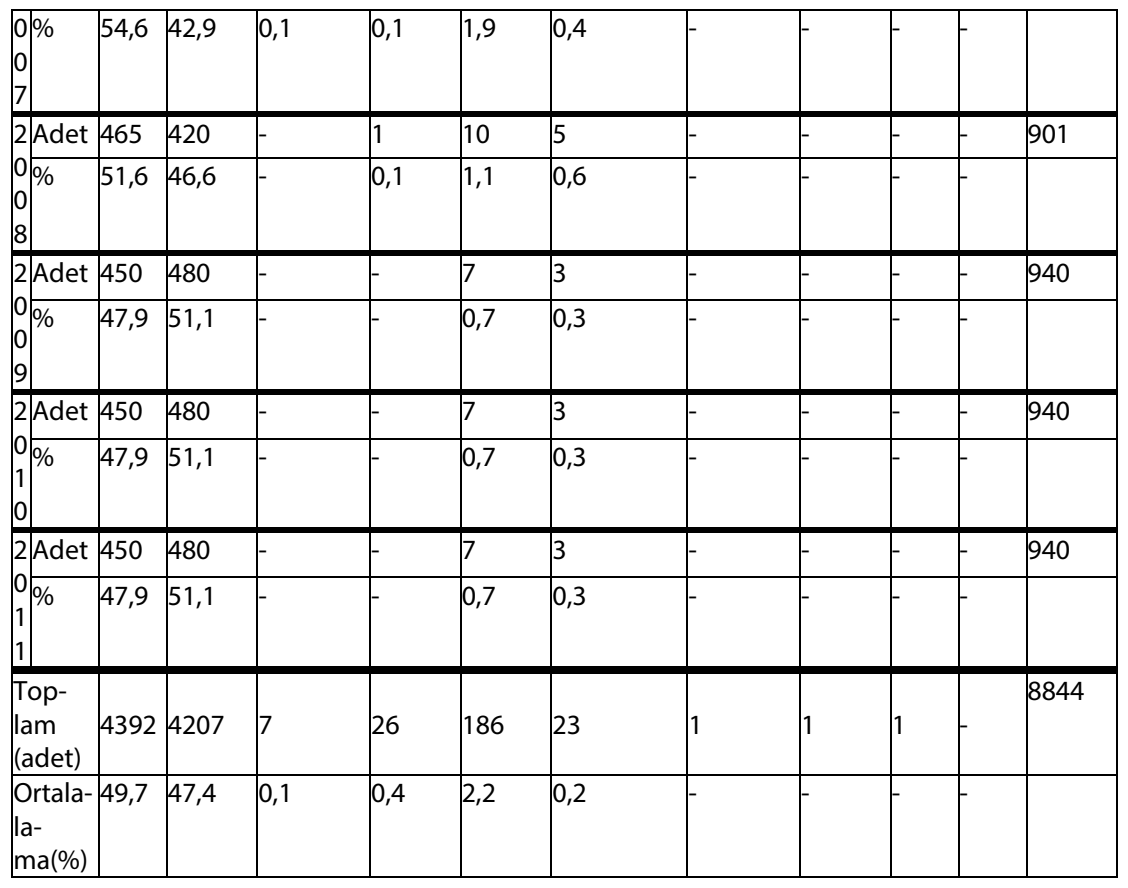

İnşaat sektörü T.C. Merkez Bankası kayıtlarına göre 2001-2002 yıllarında"alan hazırlama", "ticari binalara ait genel inşaat faaliyetleri","binaların veya bina dışı yapıların tamamının veya bölümlerinin inşaatı", "tesisat" ve "inşaatlardaki tamamlayıcı işler" olmak üzere beş ana alt gruba ayrılmaktadır. 2003-2007 yılları arasında "ticari binalara ait genel inşaat faaliyetleri" alt sektörü, "binaların veya bina dışı yapıların tamamının veya bölümlerinin inşaatı" alt sektörüne dahil edilerek sınıflandırma dörde indirilmiştir. 2008 yılından sonra ise alt sektörler bina inşaatı, bina dışı yapıların inşaatı ve özel inşaat faaliyetleri olmak üzere üçe ayrılmıştır. Her ne kadar alt sektör sınıflandırılmaları değiştirilmiş olsa da, inşaat şirketleri arasında taşeron ve ihale usulü iş yapan şirketlerin bulunduğu binaların veya bina dışı yapıların tamamının veya bölümlerinin inşaatı" ve "inşaatlardaki tamamlayıcı işler" alt sektörlerinin baskın olduğu ve sektörün yaklaşık \%70'ini oluşturduğu görülmektedir. Bu nedenle, bilançonun karakterini bu iki alt sektör açısından değerlendirmek daha doğru olacaktır. Bu iki alt sektördeki uygulamalara bakılacak olursa, yapılan iş programlarının aylık bazda olduğu ve her ay yapılacak olan imalata esas hammadde alışı yapıldığı görülmektedir. İs programı yapı sahibince tanımlanan ödeneklere göre yapılmaktadır. Uygulamada imalata esas üretim giderlerinden olan işçilik genellikle taşeron eliyle yapılmaktadır. Hammadde (inşaat malzemesi) alımı borçlanarak yapılmaktadır. Aylık imalat ve ihzarat karşılığı hak ediş adı altında her ayın sonunda düzenlenmekte, incelenmesi ve ödenmesi 1-2 ayı bulmaktadır.

Tablo 2. Çalışmaya katılan şirketlerin alt sektörlere göre dağılımı

\begin{tabular}{|l|l|l|l|l|l|l|l|l|l|l|l|}
\hline & $\mathbf{2 0 0 1}$ & $\mathbf{2 0 0 2}$ & $\mathbf{2 0 0 3}$ & $\mathbf{2 0 0 4}$ & $\mathbf{2 0 0 5}$ & $\mathbf{2 0 0 6}$ & $\mathbf{2 0 0 7}$ & $\mathbf{2 0 0 8}$ & $\mathbf{2 0 0 9}$ & $\mathbf{2 0 1 0}$ & $\mathbf{2 0 1 1}$ \\
\hline $\begin{array}{l}\text { Inşaat alanının ha- } \\
\text { zırlanmasına yöne- } \\
\text { lik inşaat faaliyetleri }\end{array}$ & 67 & 57 & 49 & 50 & 50 & 40 & & & & \\
\hline $\begin{array}{l}\text { Ticari binalara ait } \\
\text { genel inşaat faali- } \\
\text { yetleri }\end{array}$ & 70 & & & & & & & & & \\
\hline Tesisat & 76 & 73 & 64 & 66 & 62 & 53 & 50 & & & & \\
\hline
\end{tabular}


6 Gülben Çalış

\begin{tabular}{|c|c|c|c|c|c|c|c|c|c|c|c|}
\hline $\begin{array}{l}\text { Binaların veya bina } \\
\text { dışı yapıların ta- } \\
\text { mamının veya bö- } \\
\text { lümlerinin inşaatı }\end{array}$ & & 324 & 453 & 468 & 468 & 550 & 641 & & & & \\
\hline \begin{tabular}{|ll} 
Inşaatlardaki & ta- \\
mamlayıcı işler & \\
\end{tabular} & 226 & 167 & 145 & 127 & 120 & 78 & 67 & & & & \\
\hline Bina inşaatı & & & & & & & & 584 & 604 & 604 & 604 \\
\hline $\begin{array}{l}\text { Bina dışı yapıların } \\
\text { inşaatı }\end{array}$ & & & & & & & & 180 & 187 & $\mid 187$ & 187 \\
\hline $\begin{array}{l}\text { Özel inşaat faaliyet- } \\
\text { leri }\end{array}$ & & & & & & & & 137 & 149 & 149 & 149 \\
\hline Toplam & 762 & 701 & 719 & 710 & 700 & 733 & 798 & 901 & 940 & 940 & 940 \\
\hline
\end{tabular}

3.İnşaat Sektörünün AktifYapısı

Bilanço, kısaca şirketin belirli bir tarihte sahip olduğu varlıklar ile bu varlıkların sağlandığı kaynakları gösteren finansal tablodur. Bilançonun aktifinde şirketin sahip olduğu değerler,pasifinde ise bu varlıkları elde etmek için gerekli finansmanın nerelerden temin edildiği belirtilir (Ceylan, 1995).

Bilançonun aktif varlıklar kısmı, dönen ve duran varlıklar olmak üzere ikiye ayrılır. Tüm sektörler ve inşaat sektöründe dönen varlıklara ait oranlar Tablo 3.'de gösterilmektedir.

Tablo 3.Tüm sektörler ve inşaat sektöründe dönen varlık oranları

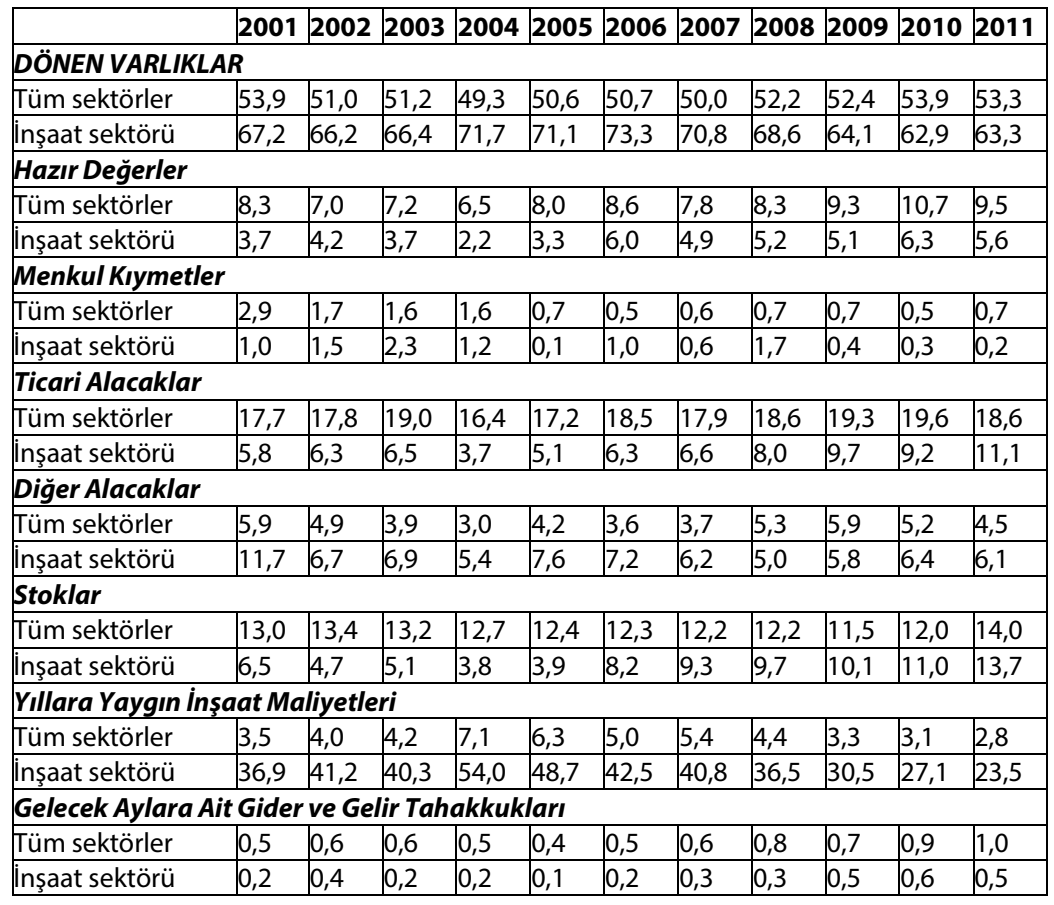


Diğer Dönen Varlıklar

\begin{tabular}{|l|l|l|l|l|l|l|l|l|l|l|l|}
\hline Tüm sektörler & 2,1 & 1,6 & 1,6 & 1,5 & 1,4 & 1,7 & 1,8 & 1,9 & 1,8 & 1,9 & 2,2 \\
\hline Inşaat sektörü & 1,3 & 1,3 & 1,5 & 1,2 & 1,5 & 1,9 & 2,0 & 2,1 & 2,1 & 2,1 & 2,5 \\
\hline
\end{tabular}

Tablo3. incelendiğinde, dönen varlıkların toplam varlıklar içerisindeki oranları tüm sektörlerde ortalama \%52iken inşaat sektöründe \%68değerine ulaşması inşaat sektörünün emek yoğun bir sektör olması ve inşaat şirketlerinin yapılacak işlerle ilgili harcamalarının dönen varlıklar içerisinde gösterilmesinden kaynaklanmaktadır. Sektörde makinelerde çoğunlukla kiralama yoluna gidilmesi, taşeron kullanımının tercih edilmesi duran varlıkların düşük olmasına yol açmaktadır.Bu bölümde inşaat sektörü açııından önemli bazı dönen varlık oranları değerlendirilmektedir.

Hazır değerler likiditelerine göre sıralanırlar. Nakit olarak elde tutulan, bankada bulunan ve istenildiğinde kolayca nakde dönüştürülebilen değerlerdir; kasa hesabı, alınan çekler hesabı, bankalar hesabı ve diğer hazır değerler hesabı sayılabilir. İnşaat sektöründe hazır değerler oranının, tüm sektörler oranının yaklaşık yarısı olduğu görülmektedir. İnşaat sektöründe hazır değer kullanım yerleri hammadde ve işçiliktir. Bunlar hemen ihtiyaç duyulan ve karşılanan yerler olduklarından, sektörde üretilecek kadar hammadde alınması veya elde tutulması tercih edilmektedir. Bunun sektörün yapısına bağlı bir davranış olduğu söylenebilir. Yıllar bazında hazır değer oranlarının yaklaşık 3 katına çıkması ise politik değişimlere bağı olabilmektedir.

Ticari alacaklar, diğer sektörlere benzer olarak inşaat sektöründe de ticari faaliyetlerinden dolayı oluşan ve bir yıl içerisinde tahsil edilebilen senetli ve senetsiz borçlar olarak dönen varlıklar arasında yer almaktadır. Alıcılar, alacak senetleri, verilen depozito ve teminatlar, şüpheli ticari alacaklar gibi alt bölümlerden oluşur. İnşaat sektörünün diğer sektörlerde olduğu gibi dışarıya mamul ya da hizmet sunuşu olmadığı için bu ka- 
lemin oranı düşüktür. Diğer sektörlere göre üçte biri oranında olan bu kalemin, endüstriyel üretim şeklinde olan yap-satçılık, prefabrike ve tesisat tipi üretim yapan firmaların bilançolarından oluştuğu söylenebilir.

Stoklar, dönen varlıklar içinde bir diğer kalemi oluşturmaktadır. Yarı mamuller, mamuller, ticari mallar, diğer stoklar ve verilen sipariş avanslar bu grupta gösterilir. İņ̧aat sektöründe stoklar içerisindeki kavramlar diğer sektörlerden farklılık göstermektedir. Bir katın betonu ya da kalıp işi mamul olarak değerlendirilebileceğinden stoklar hemen mamule dönüşür durumdadır. Stok kalemlerinde görülen oranlar, tüm sektörlerin yaklaşık yarısı kadardır. Bilançoda görülen rakamlar dönemin son ayını göstermektedir. Inş̧aatta hak ediş yapıldıktan sonra alınan hammadde bu kalemde yer almakta, bu nedenle oranlar düşük olmaktadır. Sürekli üretim tipinde çalışan alt sektörlerin stokları da bilançoda görünen oranın oluşmasında etkin olmaktadır. Yıllara bağlı olarak stoklardaki değişim incelendiğinde, 2005 yılından itibaren inşaat sektöründe stoklarda artış olduğu gözlenmektedir. Bu artışın nedeninin 2005 yılından itibaren inşaat sektörü içerisinde konut sektörünün payının artması ve altyapı işlerinin (baraj vb.) payının azalması olduğu söylenebilir.

Şirketlerin üstlendiği yapım ve onarım işlerinin tamamlanan bölümleri karşılığında aldığı hak edişler ile tesis, bina vb. yatıımlarla ilgili harcamalar yıllara yaygın inşaat ve onarım hak edişleri adı altında toplanmaktadır. Taşeronlara verilen avanslar da bu kalemde yer almaktadır. Dönen varlıkların \%25-40'ını oluşturan bu kalem sektörün belirleyici yapısını göstermektedir. Inşaat sektöründeki oranlar, tüm sektörlerdeki oranların da yaklaşık 10 katıdır. Bu kalemin açılımı yapılacak olursa taşeronlara verilen avansların da bu kalemde yer aldığı görülmektedir. Esas belirgin olan kalemise hak edişe bağlanmış, incelemesi yapılmakta olan ve ödenmemiş ihzarat ve imalattan oluşmaktadır. Sektörün bütün çalışma sermayesinin yarısından fazlasının hak edişe bağlı olduğu görülmektedir. Bu durum, hammadde alımının ve işçilere ödenen ücretlerin tamamen hak edişlere bağlı olarak seyrettiğini göstermekte ve sektörün yapısını tam olarak yansıtmaktadır.Inşaat sektöründe yıllar bazında oranların dalgalanmasının politik nedenlere bağlı olduğu söylenebilir. 2005 yılından itibaren altyapı yatırımlarının azalması ve dolayısıyla hak edişlerin düşmesi de son yıllardaki oranların düşmesine neden olmaktadır.

İnşaat sektörünün dönen varlık yapısı yıllar bazında Şekil 1.'de görülmektedir. 


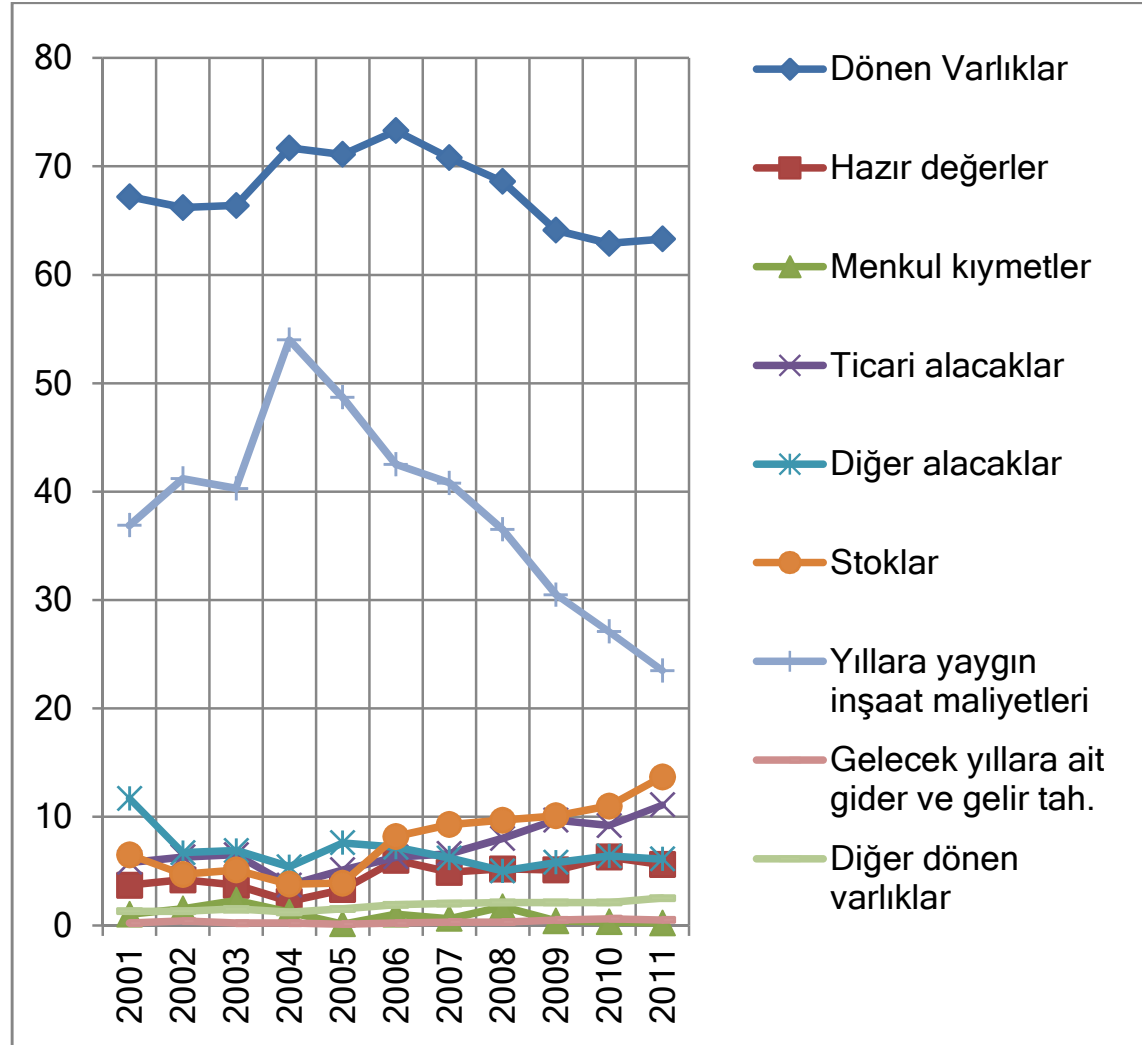

Bilançonun aktif kısmının ikinci bölümünü oluşturan duran varlıklar bir yıldan veya şirketin faaliyet döneminden daha uzun sürede kullanılacak veya değerlendirilecek varlıkları kapsamaktadır. Alt bölümleri; ticari alacaklar, diğer alacaklar, mali duran varlıklar, maddi duran varlıklar, maddi olmayan duran varlıklar, gelecek yıllara ait giderler ve diğer duran varlıklardır. Tüm sektörler ve inşaat sektöründe duran varlıklara ait oranlar Tablo 4.'de gösterilmektedir.Duran varlıkların tüm sektörlerdeki oranı yaklaşık \%50 iken, bu oranın inşaat sektöründe yaklaşık \%30'larda olduğu görülmektedir. Sektörün doğası gereği yatırımlarının az olması, işlerinde daha çok taşeron kullanması ve makine parkını kiralama yoluna gitmesi duran varlık oranlarının düşük olmasına yol açmaktadır. Bu bölümde inşaat sektörü açııından önemli bazı duran varlık oranları değerlendirilmektedir.

Tablo 4.Tüm sektörler ve inşaat sektöründe duran varlık oranları 


\begin{tabular}{|c|c|c|c|c|c|c|c|c|c|c|c|}
\hline \multirow{2}{*}{\multicolumn{12}{|c|}{\begin{tabular}{|l|l|} 
& 200 \\
DURAN VARLIKLAR
\end{tabular}}} \\
\hline & & & & & & & & & & & \\
\hline \multicolumn{12}{|c|}{\begin{tabular}{|l|l} 
Tüm sektörler & 46,1
\end{tabular}} \\
\hline Inşaat sektörü & 32,8 & 33,8 & 33,6 & 28,3 & 28,9 & 26,7 & 29,2 & 31,4 & 35,9 & 37,1 & 36,7 \\
\hline \multicolumn{12}{|c|}{ Ticari Alacaklar } \\
\hline Tüm sektörler & 0,6 & 0,2 & 0,2 & 0,3 & 0,3 & 0,3 & 0,2 & 0,3 & 0,3 & 0,3 & 0,4 \\
\hline Inşaat sektörü & 0,7 & 0,7 & 0,7 & 0,4 & 0,5 & 0,5 & 0,5 & 0,5 & 0,9 & 0,7 & 1,0 \\
\hline \multicolumn{12}{|c|}{ Diğer Alacaklar } \\
\hline Tüm sektörler & 1,4 & 1,7 & 1,8 & 1,0 & 1,1 & 1,0 & 0,9 & 0,8 & 0,7 & 0,9 & 0,8 \\
\hline Inşaat sektörü & 3,8 & 2,3 & 3,4 & 1,5 & 2,6 & 1,4 & 1,8 & 1,8 & 1,3 & 1,8 & 1,9 \\
\hline \multicolumn{12}{|c|}{ Mali Duran Varlıklar } \\
\hline Tüm sektörler & 10,5 & 9,6 & 10,4 & 16,1 & 16,5 & 16,9 & 16,7 & 13,6 & 12,3 & 11,9 & 11,9 \\
\hline Inşaat sektörü & 9,1 & 7,3 & 9,0 & 11,6 & 10,7 & 9,4 & 11,0 & 9,1 & 11,5 & 11,5 & 11,0 \\
\hline \multicolumn{12}{|c|}{ Maddi Duran Varlıklar } \\
\hline Tüm sektörler & 30,5 & 32,8 & 31,6 & 29,5 & 27,7 & 25,2 & 25,9 & 26,3 & 27,0 & 26,3 & 26,9 \\
\hline Inşaat sektörü & 16,4 & 18,2 & 15,1 & 11,4 & 12,0 & 11,5 & 12,5 & 17,3 & 19,5 & 20,6 & 20,3 \\
\hline \multicolumn{12}{|c|}{ Maddi Olmayan Duran Varlıklar } \\
\hline Tüm sektörler & 2,1 & 3,8 & 4,0 & 2,9 & 2,8 & 5,0 & 5,2 & 5,6 & 6,2 & 5,6 & 5,5 \\
\hline Inşaat sektörü & 0,4 & 2,6 & 2,3 & 1,6 & 1,0 & 1,8 & 1,6 & 1,3 & 1,5 & 1,2 & 1,2 \\
\hline \multicolumn{12}{|c|}{ Özel Tükenmeye Tabi Varlıklar } \\
\hline Tüm sektörler & 0,1 & 0,1 & 0,1 & 0,2 & 0,2 & 0,2 & 0,2 & 0,2 & 0,2 & 0,2 & 0,3 \\
\hline Inşaat sektörü & F & 0,4 & 0,3 & 0,3 & 0,2 & 0,2 & 0,2 & 0,2 & & - & \\
\hline \multicolumn{12}{|c|}{ Gelecek Yıllara Ait Gider ve Gelir Tahakkukları } \\
\hline Tüm sektörler & 0,3 & 0,3 & 0,3 & 0,4 & 0,5 & 0,5 & 0,6 & 0,6 & 0,6 & 0,6 & 0,6 \\
\hline Inşaat sektörü & 0,4 & 0,5 & 0,7 & 0,5 & 0,5 & 0,5 & 0,5 & 0,4 & 0,4 & 0,4 & 0,7 \\
\hline \multicolumn{12}{|c|}{ Diğer Duran Varlıklar } \\
\hline Tüm sektörler & 0,6 & 0,5 & 0,4 & 0,3 & 0,3 & 0,2 & 0,4 & 0,3 & 0,3 & 0,3 & 0,3 \\
\hline Inşaat sektörü & 1,7 & 1,8 & 2,1 & 1,2 & 1,4 & 1,4 & 1,1 & 0,9 & 0,8 & 0,8 & 0,7 \\
\hline
\end{tabular}

Yasal zorunluluk nedeniyle veya uzun vadeli yatırım amacıyla şirketlerin ellerinde bulunan menkul kıymetler ile şirketlerin farkı işletmelerdeki iştirakleri ve bağlı ortaklıklara ait sermaye payları mali duran varlıklar adı altında toplanmaktadır. İnşaat sektöründe de önemli bir yeri olan mali duran varlıkların özellikle son yıllarda artış görülmekte ve incelendiğinde inşaat sektörünün iştiraklere ve bağlı ortaklıklara katııımlarının son yıllarda tüm sektörlere ait değerlere yetişmekte olduğu belirlenmiştir. İnşaat işlerinin azalmasıyla şirketlerin ellerinde bulunan atıl fonları iştiraklerde ve bağlı ortaklıklarda değerlendirme yoluna gitmeleri bu sonucun çıkmasında etkili olmuştur. Ayrıca, inşaat sektöründe üretim olduğu sürece finansal yatırıma gitme intiyacının azaldığı ve bütün fonların üretime yönlendirildiği bilinmektedir. Bu durum enflasyonist ortamlarda tam tersi olmaktadır. Son yıllarda enflasyonist ortamdan çıkılması da inşaat sektöründeki mali duran varlık oranlarının tüm sektörlerdeki oranlara yaklaşmasını açıklamaktadır.

Her iki sektör için duran varlıklarda en önemli kısım maddi duran varlıklardır. Maddi duran varlıklar, şirketlerin mal veya hizmet üretmek gibi faaliyetlerini gerçekleştirebilmek amacıyla kullandığı her türlü tesis, araç, makine, ekipman vb. fiziki varlıklardan oluşan bölümdür. Arazi ve arsalar, yer altı ve yerüstü düzenleri, binalar, tesis, makine ve cihazlar, taşıtlar, demirbaşlar, yapılmakta olan yatırımların bu varlıklar arasında olduğu görülür. İnşaat sektörünün dışındaki sektörlerde duran varlıkların oranının ortalama \%30 
olduğu görülmektedir. Bu durum, diğer sektörlerin üretim biçimlerinin sürekli olmasından ve buna bağlı olarak tesis, makine ve teçhizat ile binalara yatırım yapmasından kaynaklanmaktadır. İnşaat sektöründe işlerin süreksiz ve değişken türde olması nedenleriyle çekirdek makine-teçhizat kalemi küçük tutulmak zorundadır.

İnşaat sektörünün duran varlık yapısı yıllar bazında Şekil 2.'de görülmektedir.

Şekil 2. İnşaat sektörünün duran varlık yapısı

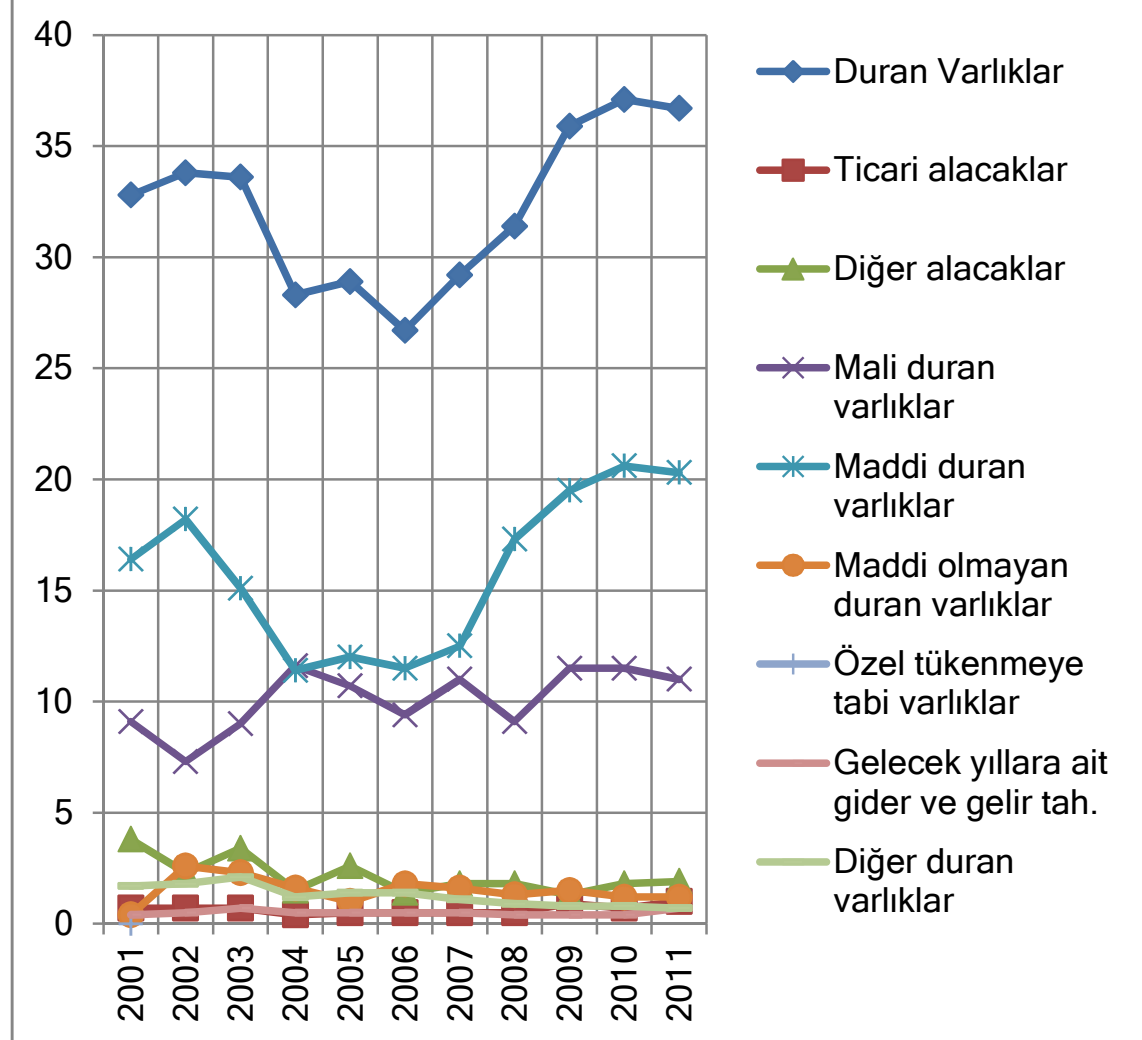

İnşaat sektörünün aktif yapısının dağılımı yıllar bazında Şekil 3.'de görülmektedir.

Şekil 3. İnşaat sektörünün aktif yapısı 


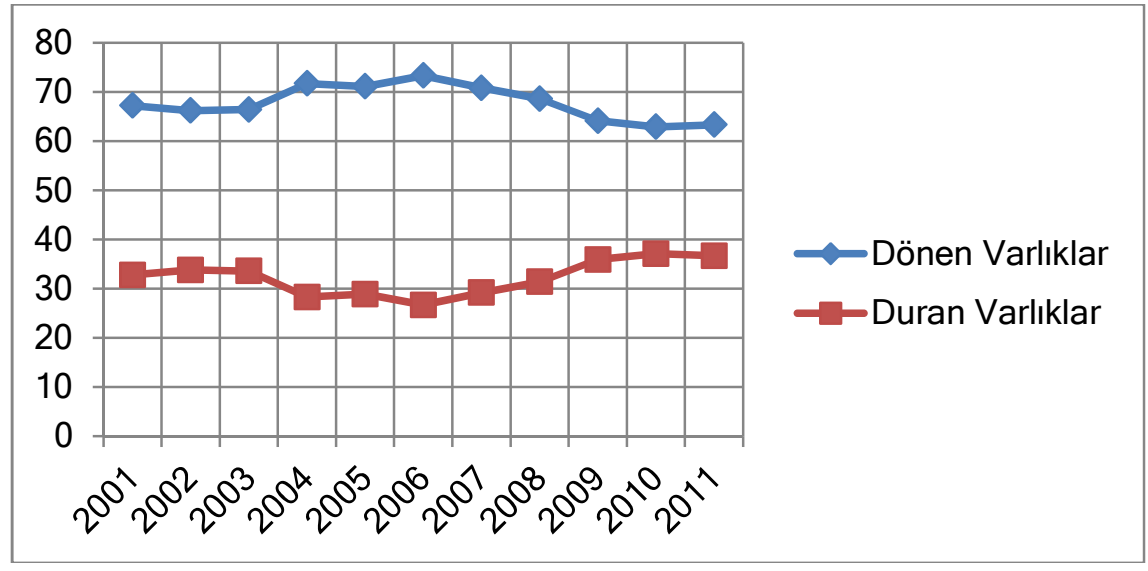

\section{4. İnşaat Sektörünün Pasif Yapısı}

Bilançonun pasif kısmında şirketin işlerinin yürütülmesi için dönen ve duran varlıklara yaptığı yatırımların kaynaklarını nereden temin edildiği gösterilmektedir. Bilançonun pasif tarafı, kısa vadeli yabancı kaynaklar, uzun vadeli yabancı kaynaklar ve öz kaynaklardan oluşmaktadır.

Kısa vadeli yabancı kaynaklar bir yıl veya daha az süreli borçlardır ve genellikle şirketin çalışma sermayesini karşılamakta kullanılmaktadır. Mali borçlar, ticari borçlar, alınan avanslar, diğer borçlar ve yıllara yaygın inşaat ve onarım hak edişleri bu grupta yer almaktadır. Bu kalemlerden mali borçlar, bankalardan ve kredi kurumlarından temin edilmiş vade süresi bir yılı geçmeyen borçları göstermektedir. En büyük kısmını banka kredileri oluşturmaktadır. Ticari borçlar ise şirketlerin ticari faaliyetleri sonucunda oluşan senetli veya senetsiz kısa vadeli borçlardır. Satıcılar ve borç senetleri bu alt gruba dâhildir. Diğer borçlar ise şirketin ticari faaliyetlerinden kaynaklanmayan vadesi bir yıldan kısa olan borçları kapsamaktadır. Ortaklara, iştiraklere, bağlı ortaklara ve personele olan borçlar bu gruptadır. Şirketlerin gelecekte yapacağı hizmet veya mal teslimleriyle ilgili peşin tahsil ettiği tutarlar olarak adlandırılan avanslar da kısa vadeli yabancı kaynaklardandır. Tüm sektörler ve inşaat sektöründe kısa vadeli yabancı kaynaklara ait oranlar Tablo 5.'de gösterilmektedir.

Tablo 5. Tüm sektörler ve inşaat sektörü kısa vadeli yabancı kaynaklar yapısı

\begin{tabular}{|c|c|c|c|c|c|c|c|c|c|c|c|}
\hline & 2001 & 2002 & 2003 & 2004 & 2005 & 2006 & 2007 & 2008 & 2009 & 2010 & 2011 \\
\hline \multicolumn{12}{|c|}{ KISA VADELI YABANCI KAYNAKLAR } \\
\hline Tüm sektörler & 47,8 & 40,1 & 38,4 & 35,8 & 36,1 & 36,5 & 36,0 & 40,7 & 39,0 & 38,7 & 37,8 \\
\hline İnşaat sektörü & 65,3 & 60,0 & 58,8 & 65,4 & 63,6 & 62,5 & 60,3 & 60,0 & 57,0 & 52,2 & 51,7 \\
\hline \multicolumn{12}{|l|}{ Mali Borçlar } \\
\hline Tüm sektörler & 15,4 & 10,8 & 9,5 & 7,7 & 8,6 & 9,5 & 8,9 & 10,6 & 8,7 & 9,3 & 10,6 \\
\hline Inşaat sektörü & 11,9 & 6,4 & 6,2 & 3,0 & 4,1 & 4,5 & 5,2 & 6,9 & 8,2 & 7,5 & 7,2 \\
\hline \multicolumn{12}{|l|}{ Ticari Borçlar } \\
\hline Tüm sektörler & 15,9 & 15,6 & 15,5 & 13,1 & 13,6 & 14,3 & 13,7 & 15,2 & 15,5 & 16,2 & 14,6 \\
\hline Inşaat sektörü & 6,9 & 5,7 & 5,5 & 3,3 & 4,1 & 6,1 & 5,4 & 6,7 & 8,4 & 7,6 & 8,0 \\
\hline \multicolumn{12}{|l|}{ Diğer Borçlar } \\
\hline Tüm sektörler & 4,9 & 3,6 & 3,1 & 2,4 & 2,6 & 2,8 & 2,8 & 5,3 & 6,3 & 4,6 & 3,8 \\
\hline
\end{tabular}




\begin{tabular}{|c|c|c|c|c|c|c|c|c|c|c|c|}
\hline Inşaat sektörü & 7,0 & 2,4 & 2,7 & 1,6 & 2,0 & 4,8 & 3,8 & 4,3 & 4,9 & 3,8 & 3,4 \\
\hline \multicolumn{12}{|l|}{ Alınan Avanslar } \\
\hline Tüm sektörler & 1,8 & 1,9 & 1,9 & 1,8 & 1,9 & 1,9 & 2,0 & 2,0 & 1,8 & 2,1 & 2,6 \\
\hline Inşaat sektörü & 3,1 & 1,9 & 2,3 & 2,1 & 3,2 & 3,6 & 3,3 & 3,2 & 3,0 & 4,1 & 7,8 \\
\hline \multicolumn{12}{|c|}{ Yıllara Yaygın Inşaat ve Onarım Hakedişleri } \\
\hline Tüm sektörler & 3,4 & 4,1 & 4,3 & 7,2 & 6,3 & 5,0 & 5,4 & 4,5 & 3,4 & 3,1 & 2,8 \\
\hline Inşaat sektörü & 34,5 & 41,8 & 40,4 & 54,5 & 49,4 & 42,6 & 41,3 & 37,6 & 31,1 & 27,6 & 23,5 \\
\hline \multicolumn{12}{|c|}{ Ödenecek Vergi ve Diğer Yükümlülükler } \\
\hline Tüm sektörler & 2,0 & 1,7 & 1,7 & 1,5 & 1,5 & 1,3 & 1,4 & 1,5 & 1,6 & 1,5 & 1,4 \\
\hline Inşaat sektörü & 0,8 & 0,7 & 0,5 & 0,4 & 0,4 & 0,5 & 0,4 & 0,5 & 0,5 & 0,4 & 0,6 \\
\hline \multicolumn{12}{|c|}{ Borç ve Gider Karşılıkları } \\
\hline Tüm sektörler & 3,0 & 1,6 & 1,4 & 1,3 & 0,9 & 0,9 & 0,9 & 0,7 & 0,7 & 0,7 & 0,7 \\
\hline Inşaat sektörü & 0,6 & 0,4 & 0,4 & 0,1 & 0,1 & 0,1 & 0,2 & 0,2 & 0,2 & 0,2 & 0,2 \\
\hline \multicolumn{12}{|c|}{ Gelecek Aylara ait Gelir ve Gider Tahakkukları } \\
\hline Tüm sektörler & 0,8 & 0,6 & 0,7 & 0,6 & 0,5 & 0,5 & 0,6 & 0,6 & 0,8 & 0,8 & 0,9 \\
\hline Inşaat sektörü & 0,5 & 0,3 & 0,5 & 0,2 & 0,3 & 0,2 & 0,4 & 0,3 & 0,4 & 0,7 & 0,7 \\
\hline \multicolumn{12}{|c|}{ Diğer Kısa Vadeli Yabancı Kaynaklar } \\
\hline Tüm sektörler & 0,6 & 0,2 & 0,3 & 0,4 & 0,3 & 0,3 & 0,3 & 0,3 & 0,3 & 0,3 & 0,3 \\
\hline İş̧aat sektörü & 0,1 & 0,4 & 0,3 & 0,1 & 0,1 & 0,2 & 0,3 & 0,3 & 0,2 & 0,4 & 0,3 \\
\hline
\end{tabular}

İnşaat sektöründe yabancı kaynaklara kısa vadeli ihtiyaç duyulduğu ve kendini finanse etme eğiliminde olduğu görülmektedir. Bunun nedeni, sektörün yapısı gereği uzun vadeli yatııımlara makine parkı dışında ihtiyaç duymaması olabilir. Sektörün kısa vadeli borçlanma oranının $\% 50^{\prime} l e r$ ve üzerinde seyretmesi hammadde alımını borçla yapması ve taşeronlara olan önemli miktarlardaki borçlardan kaynaklanmaktadır. Kısa vadeli borçlanma oranının yıllar bazında azaldığı dikkat çekmektedir. Kısa vadeli yabancı kaynakların yıllar bazında dağııımı Şekil 4.'de görülmektedir. 


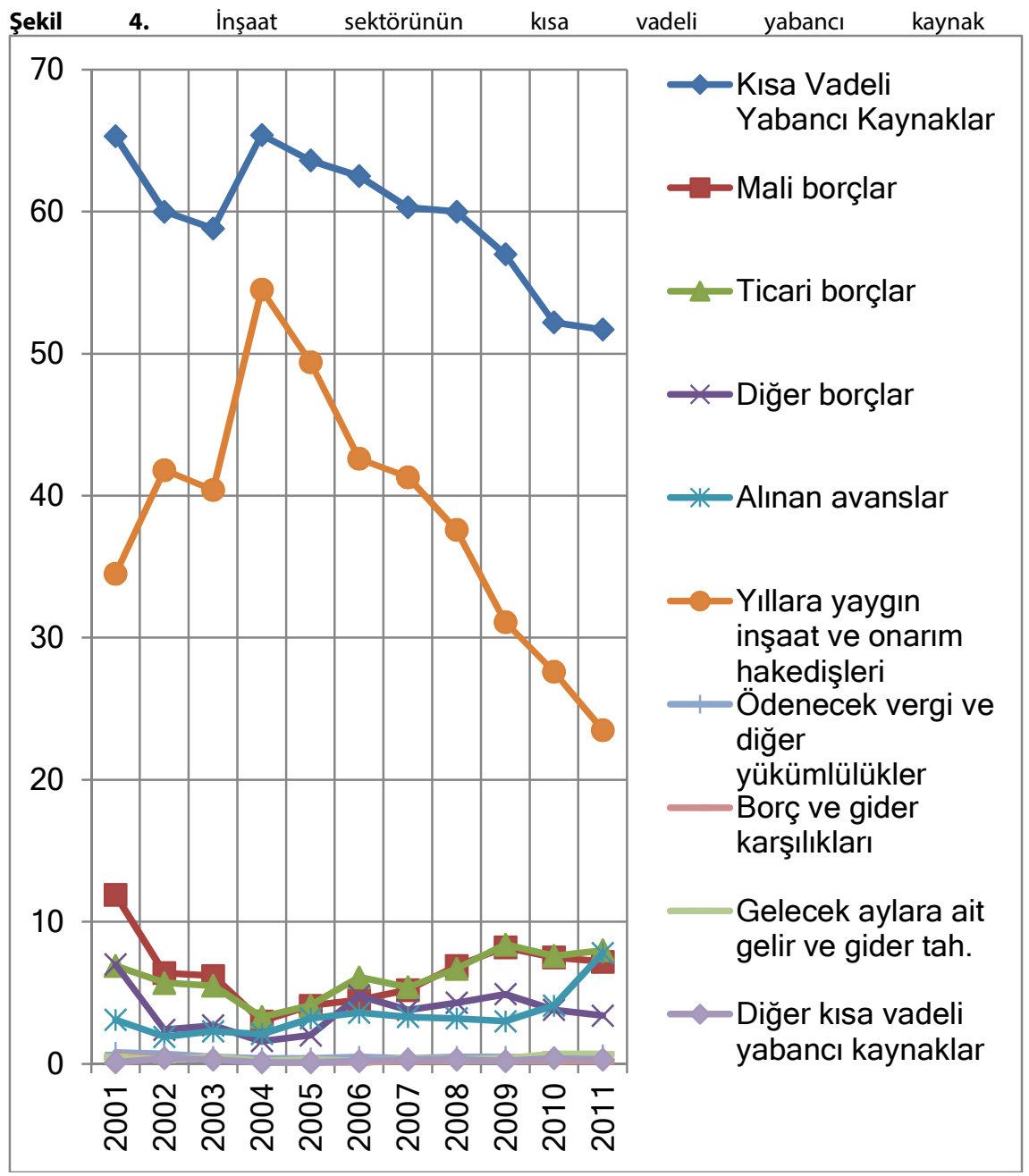

Uzun vadeli yabancı kaynaklar vadesi bir yıldan fazla olan borçlar olarak tanımlanmıştır. Mali borçlar, ticari borçlar, alınan avanslar, diğer borçlar, borç ve gider karşılıkları ve gelecek yıllara ait gelir ve gider tahakkukları vb. kalemlerden oluşmakta ve kısa vadeli yabancı kaynaklarda yapılan tanımlamalara benzemektedir. En önemli farkı sürenin bir yılı aşkın olmasıdır. Tüm sektörler ve inşaat sektöründe kısa vadeli yabancı kaynaklara ait oranlar Tablo 6.'da gösterilmektedir. 
BILANÇOLAR ILE TÜRK INŞAAT SEKTÖRÜNÜN FINANSAL YAPISININ DEGERLENDIRILMESI - 15

Tablo 6. Tüm sektörler ve inşaat sektörü uzun vadeli yabancı kaynaklar yapısı

\begin{tabular}{|c|c|c|c|c|c|c|c|c|c|c|c|}
\hline & 2001 & 2002 & 2003 & 2004 & 2005 & 2006 & 2007 & 2008 & 2009 & 2010 & 2011 \\
\hline \multicolumn{12}{|c|}{ UZUN VADELI YABANCI KAYNAKLAR } \\
\hline Tüm sektörler & 22,3 & 23,8 & 19,1 & 12,2 & 12,9 & 14,8 & 14,9 & 16,8 & 16,4 & 17,2 & 19,4 \\
\hline İnşaat sektörü & 17,1 & 16,7 & 15,0 & 9,3 & 11,6 & 13,8 & 16,3 & 18,4 & 19,1 & 23,5 & 25,7 \\
\hline \multicolumn{12}{|l|}{ Mali Borçlar } \\
\hline Tüm sektörler & 15,5 & 17,6 & 14,0 & 8,6 & 8,5 & 11,2 & 11,2 & 13,1 & 12,2 & 13,2 & 15,1 \\
\hline İnşaat sektörü & 9,9 & 8,3 & 7,2 & 4,0 & 4,8 & 6,2 & 7,8 & 10,9 & 10,6 & 15,3 & 17,3 \\
\hline \multicolumn{12}{|l|}{ Ticari Borçlar } \\
\hline Tüm sektörler & 1,3 & 1,2 & 1,0 & 0,7 & 0,8 & 0,7 & 0,7 & 0,8 & 1,0 & 1,0 & 1,1 \\
\hline İnşaat sektörü & 0,6 & 0,7 & 0,5 & 0,4 & 0,5 & 0,3 & 0,6 & 0,7 & 0,8 & 0,8 & 1,0 \\
\hline \multicolumn{12}{|l|}{ Diğer Borçlar } \\
\hline Tüm sektörler & 1,7 & 2,7 & 1,9 & 1,1 & 1,5 & 1,1 & 1,0 & 1,0 & 1,0 & 0,9 & 1,0 \\
\hline İnşaat sektörü & 3,2 & 4,1 & 4,1 & 2,7 & 3,3 & 1,9 & 1,9 & 1,9 & 1,7 & 1,7 & 1,8 \\
\hline \multicolumn{12}{|c|}{ Alınan Avanslar } \\
\hline Tüm sektörler & 0,8 & 0,7 & 0,5 & 0,6 & 0,6 & 0,8 & 1,0 & 0,8 & 0,9 & 1,0 & 0,9 \\
\hline İnşaat sektörü & 2,9 & 3,1 & 2,7 & 1,7 & 2,5 & 5,1 & 5,7 & 4,7 & 5,4 & 5,4 & 5,1 \\
\hline \multicolumn{12}{|c|}{ Borç ve Gider Karşılıkları } \\
\hline Tüm sektörler & 2,5 & 1,1 & 1,2 & 1,0 & 1,0 & 0,9 & 0,8 & 0,8 & 0,8 & 0,8 & 0,8 \\
\hline Inşaat sektörü & 0,1 & 0,1 & 0,1 & 0,0 & 0,1 & 0,1 & 0,0 & 0,0 & 0,0 & 0,0 & 0,0 \\
\hline \multicolumn{12}{|c|}{ Gelecek Aylara ait Gelirler ve Gider Tahakkukları } \\
\hline Tüm sektörler & 0,2 & 0,5 & 0,4 & 0,2 & 0,2 & 0,2 & 0,2 & 0,3 & 0,3 & 0,3 & 0,3 \\
\hline inşaat sektörü & 0,4 & 0,4 & 0,5 & 0,4 & 0,4 & 0,3 & 0,3 & 0,2 & 0,5 & 0,3 & 0,4 \\
\hline \multicolumn{12}{|c|}{ Diğer Uzun Vadeli Yabancı Kaynaklar } \\
\hline Tüm sektörler & 0,3 & 0,0 & 0,0 & 0,0 & 0,2 & 0,0 & 0,0 & 0,1 & 0,1 & 0,1 & 0,1 \\
\hline Inşaat sektörü & 0,1 & 0,0 & 0,1 & 0,0 & 0,0 & 0,0 & 0,0 & 0,0 & 0,0 & 0,0 & 0,1 \\
\hline
\end{tabular}

Türkiye'de tüm sektörlerde uzun vadeli fon kullanımında bilimsel bir yaklaşım yoktur. Aynı zamanda, uzun vadeli fon kaynağı olarak kullanılacak borç veren banka bulunmamakta, tahvil piyasası aktif olarak çalışmamakta, otofinansmana gidilmemekte, hisse senedi çıkarılması söz konusu olmamaktadır. İnşaat sektöründe yabancı kaynaklarda yıllık bazda artış olduğu görülmektedir. İncelendiğinde, inşaat şirketleri fon ihtiyacının ortalama \%10'unu banka kredilerinden sağlamaktadır. Uzun vadeli yabancı kaynakların $\% 10^{\prime}$ u da kiralama karşılığı yapılmaktadır. Sektördeki uzun vadeli borçlanmanın son yıllarda tüm sektörlerdeki oranlara yakın olduğu da görülmektedir. Uzun vadeli yabancı kaynakların yıllar bazında dağılımı Şekil 5.'de görülmektedir. 
Şekil 5. İnşaat sektörünün uzun vadeli yabancı kaynak yapısı

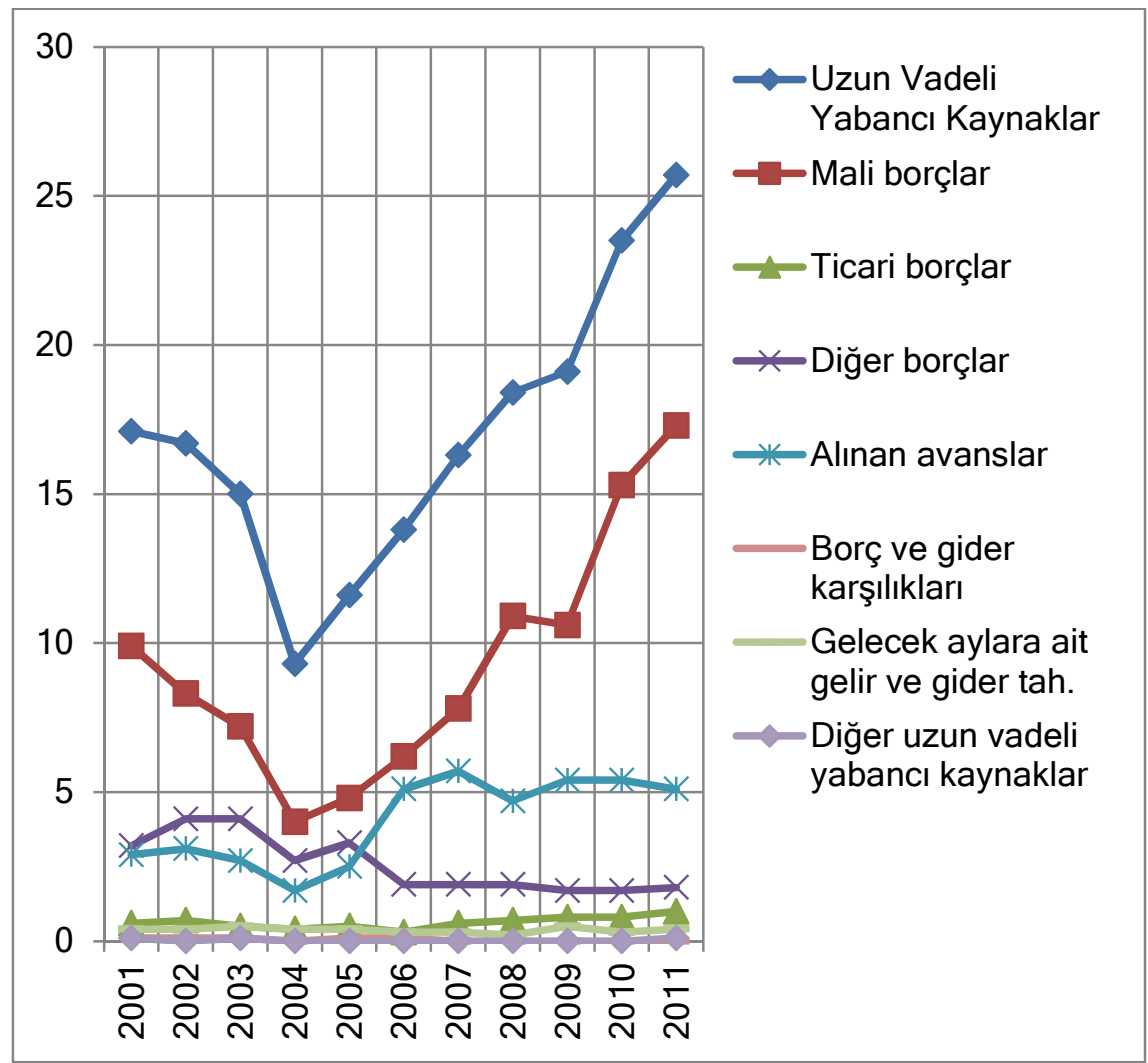

Öz kaynaklar, şirket sahip ve ortaklarının sermaye olarak taahhüt ettiği miktarın ödenmiş tutarını gösteren ödenmiş sermaye, sermaye hareketleri nedeniyle ortaya çıkarılan ve işletmede bırakılan sermaye yedekleri, dağıtılmamış ya da işletmede bırakılan kar yedekleri, geçmiş yıllara ait kar ve zararlardan oluşmaktadır.Tüm sektörler ve inşaat sektöründe özkaynaklara ait oranlar Tablo 7.'de gösterilmektedir.

Tüm sektörlerde şirketlerin pasifinin ortalama \%35'ini öz kaynaklar oluşturmaktadır. Bu oran inşaat şirketlerinin yaklaşık üç katı olduğu görülmektedir. İnşaat sektöründe duran varlıkların azlığı, sektörde seri üretim olmamasının ve dolayısıyla sektörün makine-teçhizat ve fabrikaya ihtiyaç duyulmamasının bu sonucu doğurduğu söylenebilir. Özkaynakların yıllar bazında dağılımı Şekil 6.'de görülmektedir. 
BILANÇOLAR ILE TÜRK INŞAAT SEKTÖRÜNÜN FINANSAL YAPISININ DEGERLENDIRILMESI - 17

Tablo 7. Tüm sektörler ve inşaat sektörü öz kaynaklar yapısı

\begin{tabular}{|c|c|c|c|c|c|c|c|c|c|c|c|}
\hline \multirow{2}{*}{\multicolumn{12}{|c|}{\begin{tabular}{|l|} 
\\
$\ddot{Z Z ~ K A Y N A K L A R}$ \\
\end{tabular}}} \\
\hline & & & & & & & & & & & \\
\hline Tüm sektörler & 29,9 & 36,1 & 42,5 & 52,0 & 51,0 & 48,7 & 49,2 & 42,4 & 44,6 & 44,1 & 42,8 \\
\hline Inşaat sektörü & 17,6 & 23,2 & 26,2 & 25,3 & 24,8 & 23,6 & 23,4 & 21,6 & 23,9 & 24,3 & 22,6 \\
\hline \multicolumn{12}{|c|}{ Ödenmiş Sermaye } \\
\hline Tüm sektörler & 16,3 & 19,2 & 22,6 & 48,3 & 40,1 & 36,8 & 35,4 & 31,9 & 32,3 & 31,2 & 30,4 \\
\hline İşaat sektörü & 11,0 & 11,6 & 14,6 & 13,7 & 14,8 & 15,9 & 15,0 & 13,6 & 16,5 & 16,3 & 15,6 \\
\hline \multicolumn{12}{|c|}{ Sermaye Yedekleri } \\
\hline Tüm sektörler & 13,9 & 17,4 & 16,7 & 1,6 & 1,9 & 2,3 & 2,8 & 2,7 & 3,5 & 3,4 & 3,6 \\
\hline İşaat sektörü & 4,2 & 7,6 & 6,9 & 2,0 & 1,0 & 1,0 & 1,0 & 0,6 & 0,8 & 1,3 & 1,4 \\
\hline \multicolumn{12}{|l|}{ Kar Yedekleri } \\
\hline Tüm sektörler & 3,8 & 3,4 & 4,5 & 9,8 & 10,6 & 8,5 & 9,0 & 8,3 & 9,2 & 9,1 & 9,7 \\
\hline Inşaat sektörü & 3,3 & 3,0 & 2,5 & 3,3 & 3,6 & 2,3 & 2,6 & 2,1 & 2,7 & 2,7 & 2,7 \\
\hline \multicolumn{12}{|c|}{ Geçmiş Yıllar Karları } \\
\hline Tüm sektörler & 1,0 & 1,0 & 1,1 & 6,8 & 6,0 & 4,9 & 4,5 & 4,2 & 4,6 & 4,8 & 5,2 \\
\hline İşaaat sektörü & 1,0 & 1,2 & 1,6 & 7,7 & 6,8 & 4,8 & 4,4 & 3,2 & 4,2 & 4,4 & 5,3 \\
\hline \multicolumn{12}{|c|}{ Geçmiş Yıllar Zararları } \\
\hline Tüm sektörler & $-4,6$ & $-7,9$ & $-7,9$ & $-18,9$ & $-11,4$ & $-8,6$ & $-7,4$ & $-6,8$ & $-8,3$ & $-8,3$ & $-8,3$ \\
\hline İş̧aat sektörü & $-1,5$ & $-2,5$ & $-2,6$ & $-2,3$ & $-2,6$ & $-2,5$ & $-2,1$ & $-1,3$ & $-2,9$ & $-2,8$ & $-2,7$ \\
\hline \multicolumn{12}{|c|}{ Dönem Net Karı (Zararı) } \\
\hline Tüm sektörler & $-0,5$ & 3,1 & 5,5 & 4,4 & 3,8 & 4,7 & 5,0 & 2,1 & 3,3 & 3,9 & 2,2 \\
\hline İş̧aat sektörü & $-0,4$ & 2,5 & 3,2 & 0,9 & 1,2 & 2,1 & 2,5 & 3,3 & 2,6 & 2,2 & 0,2 \\
\hline
\end{tabular}

Şekil 6. İnşaat sektörünün özkaynaklar yapısı

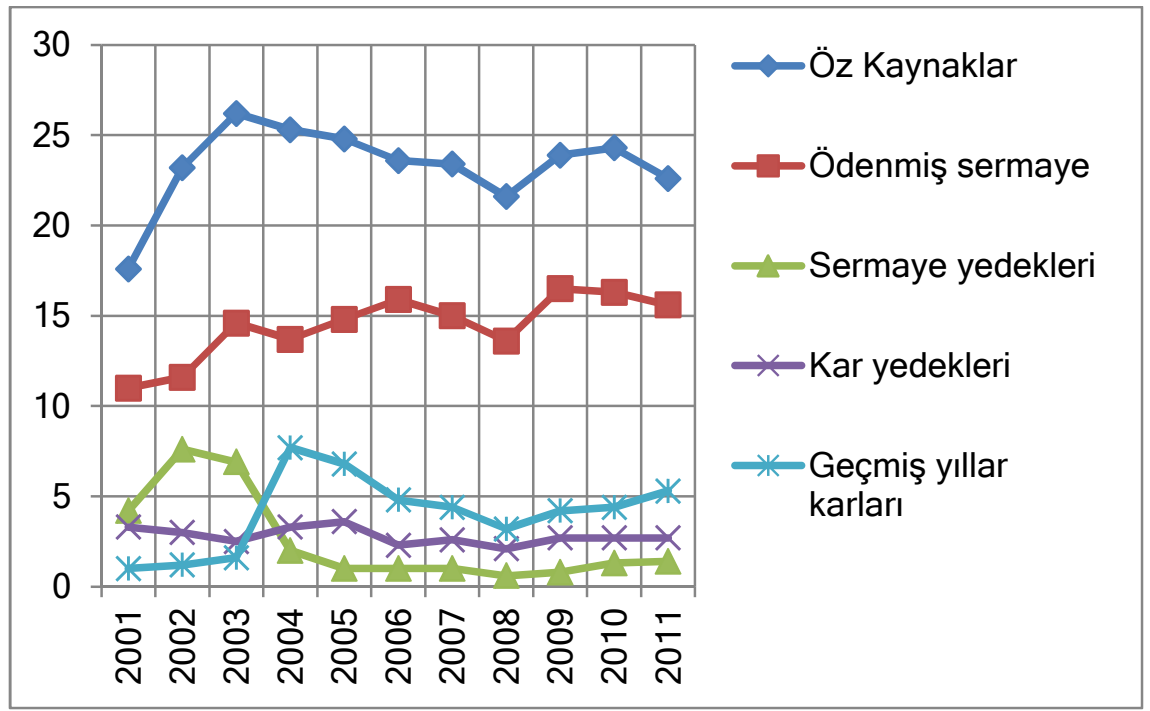


18 Gülben Çalıș

Bunun yanında, inşaat sektöründe faaliyet gösteren şirketlerde diğer sektörlere göre fazla sermaye yatırımı istememesi, işlerin daha çok hak ediş ve avanslarla yürütülmesi ve bu kalemlerin de bilançonun pasifinde kısa vadeli yabancı kaynaklar içerisinde gösterilmesi nedeniyle, yabancı kaynak oranı (kısa vadeli yabancı kaynak+uzun vadeli yabancı kaynak) öz kaynakların oranından çok büyük olmaktadır.Inşaat sektörünün pasif yapısının dağılımı yıllar bazında Şekil 7.'de görülmektedir.

Şekil 7. İnşaat sektörünün pasif yapısı

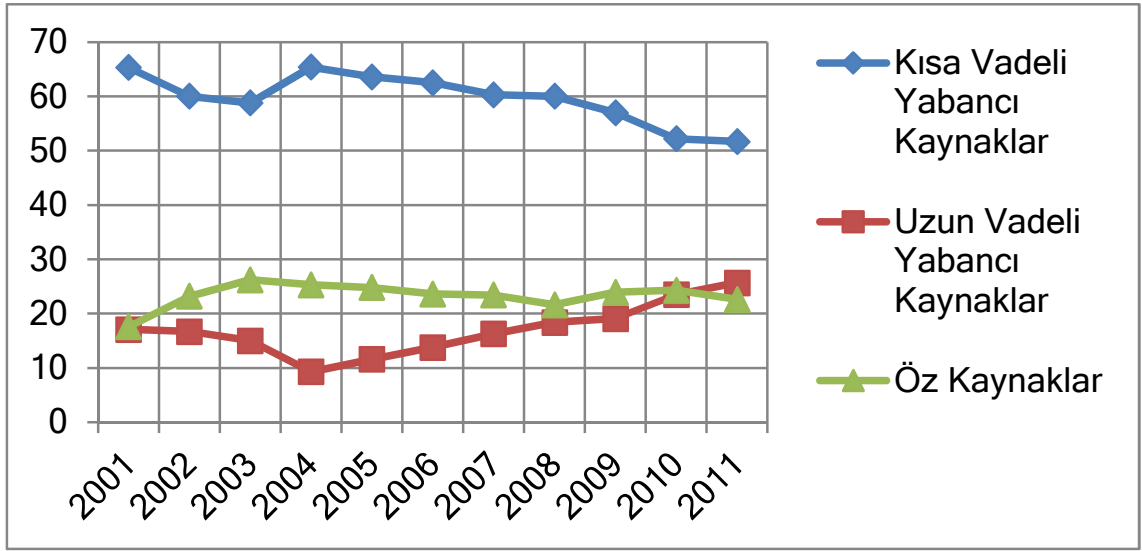

\section{SONUÇ}

Çalışmada, T.C. Merkez Bankası tarafından 2001-2011 yılları arasındayayınlananinşaat şirketinin bilanço verileri incelenerek inşaat sektörünün finansal yapısı değerlendiriliştir. Resmi kayıtlara göre Türkiye'de 100.000 civarında olan yüklenici sayısının gerçekte 400.000'leri aştığı tahmin edilmektedir. Veriler incelendiğinde, 2000 yılından 2011 yılına kadar T.C. Merkez Bankası'nda yayınlanan inşaat sektörüne ait bilanço sayısının yıllık ortalama 800 olduğu görülmektedir. Değerlendirmenin T.C. Merkez Bankası'na kayıtlı şirketlerin ağırlığını oluşturan ihale usulü iş yapan şirketlere göre yapıldığı ve enflasyonun etkisinin göz önüne alınmadığı dikkate alınmalıdır.

Bu kapsamda öncelikle inşaat sektörünün yapısının incelenmesi gerektiği görülmektedir. İnşaat sektöründe işler kısa edimli ve eser sözleşmesi kurallarına göre yapılmaktadır. Üç-dört yılı aşan işlerin varlığı bile bu durumu değiştirmemektedir. Şirketler yürüttükleri iş bittikten sonra yeni iş edinememe ya da farklı işi kabul etme durumunda olabilmektedir. Bu yapı, inşaat sektöründe faaliyet gösteren şirketlerde bilançonun aktifine fazla yatırım yapmayı engellemektedir. Şirketlerin coğrafi yapıya göre dağılabilme 
durumu bir başka deyişle aynı anda farklı bölgelerde iş yapması söz konusu olacağından organizasyon yapılarııı da dinamik olma gereği ortaya çıkmaktadır.

1970'lerde \%2-3 civarında olan sermaye şirketi oranının (Yüksel, 1970), 2000'li yıllardan sonra \%90'ların üzerine çıktığı görülmektedir (Çetin, 2002). Uzun vadeli fon kaynağı temininde (bilimsel çalışmanın etkin olduğu bir ortamın oluşması durumunda) sermaye şirketlerinin oranının yüksek olmasının iyi olacağı açıktır. Şahıs şirketlerinin aksine sermaye şirketlerinde sorumluluğun sınırlandırılması, bazı giderlerin vergi matrahından düşülebilmesi bu seçimin en büyük nedenini oluşturmaktadır.

Sektörün dönen varlıkları, aktifin 2/3 ünü ve duran varlıkların da 1/3 ünü oluşturmaktadır. Bu oranlar, tüm sektörlerde $\% 50$ 'ler civarındadır. Söz konusu farklıık, sektörün yapısından (makine-teçhizat ve fabrikaya ihtiyaç duyulmaması) kaynaklanmaktadır. 1995 yılında, bu oran inşaat sektöründe 4/5 ve 1/5 iken (Çetin, 2002)yavaş yavaş değişerek $2000^{\prime}$ li yıllarda yukarıdaki oranlara çıkmıştır. Ayrıca, inşaat şirketlerinin hak ediş alacak oranlarının da azaldığı dikkat çekmektedir. Benzer yorumlar, sektörün pasif yapısı için de geçerli olmaktadır.

$2000^{\prime} l i$ yılların başında başlayan periyotta bilançonun aktif kısmındaki dönen ve duran varlık oranlarının çok fazla dalgalanmadığı ve bunun karşıığı olarak pasif yapının da aynı kaldığı görülmektedir.

İnşaat sektörü riskli bir sektördür. Her türlü ekonomik ve siyasi konjonktürü etkileyen olaylara hemen tepki vermektedir. Bir dalgalanma çıkması halinde kamu ve özel sektörde inşaata yönelik taleplerin azalması halinde bilanço yapılarının hızla değişeceği, menkul değerlere talebin artacağı, yıllara yaygın inşaat maliyet oranının düşeceği ve pasif yapının da benzer şekilde değişeceği söylenebilir. Şu anda sektörün istikrarlı gittiği görülmektedir. Ancak, yıllara yaygın inşaat maliyetleri kaleminde $\% 5^{\prime}$ lere tırmanan oranın \%23'lere düşmesi önemli bir azalmadır ve kamu inşaatlarındaki azalmayı gösteriyor olabilir.

\section{KAYNAKÇA}

Akal, Z., Eke, N.ve Aksoy, S., 1983, Türk İnşaat ve Konut Sektörünün Güncel Sorunları, Milli Prodüktivite Merkezi Yayınları, Ankara, 238s.

Ceylan, A., 1995, İ̧letmelerde Finansal Yönetim, Ekin Kitabevi Yayınları, Bursa, 415 p.

Çetin, H.C., 2002, İnşaat Sektörünün Yapısı ve Finansal Açıdan İncelenmesi, Yüksek Lisans Tezi, Ege Üniversitesi Fen Bilimleri Enstitüsü, 134s. (yayımlanmamışı

ITO Seminer, 1988, İnşaat Sektöründe Gelişmeler, İstanbul Ticaret Odası Yayınları, İstanbul.

Manisalı, E. ve Gencer, H., 2000, Kamu Yatırım İhalelerinde İhale İndirim Oranlarını Etkileyen Faktörlerin Analizi, 2. Yapı İşletmesi Kongresi, İzmir, 89-99 s. 
20 Gülben Çalıș

Ng, S.T., Wong, J.M.W., Zhang, J., 2011, Applying Z-score modelto distinguish insolvent construction companies, Habitat International, 35(4), 599-607.

Öcal, M.E., Oral,E.L., Erdis,E., Vural, G., 2007, Industry financial ratios-application of factor analysis in Turkish Construction Industry, Building and Environment, 42(1), 385-392.

TCMB Sektör Bilançoları, 2013, Merkez Bankası Yayınları, Ankara, Türkiye.

TMB, 2009, İnşaat Sektörü Analizi, http://www.sedefed.org/default.aspx?pid=62176\&nid=59071 (erişim tarihi: 28 Mart 2013).

Yüksel, O., 1979, T.C. Bayındırlık Bakanlığı Yapı İşleri Genel Müdürlüğü'nce Yaptırılan İnşaatlardaki Gecikmelerin İncelenmesi, Doçentlik Tezi, Eskişehir DMMA, 83s. (yayımlanmamış) 